\title{
JOURNAL OF PHILOSOPHICAL STUDIES
}

were real, and real in exactly the same sense in which the Absolute is real. Nor does this involve the postulation of a single substance of which these persons are composed. but of many substances of which each of these persons is composed. And their attributes are necessary to their differentiation, since without attributes all substances are indistinguishable. This plurality is necessary to the nature of the unity in which Hegel believed. It may be difficult to refute, because it is difficult to understand. Mr. Joad may be able to do both. But his argument that the existence of illusion in the world-and Hegel's acquaintance with philosophers was not likely to influence him to a denial of such a possibility-involves a dualism which destroys the unity is vain if Hegel confesses to a multiplism. The next thing to do is to convict Hegel of contradiction in his definition of unity, and to show that plurality is incompatible with unity. This would involve picking to pieces the whole of the Dialectic upon which it rests, or, what is equally arduous, finding the exact spot where it goes wrong. It may be possible, and even in spite of it the universe may still be a unity. But so far Mr. Joad leaves us guessing.

$$
\begin{aligned}
& \text { Yours faithfully, } \\
& \text { Bertram Henson. }
\end{aligned}
$$

30, Regent's Court,

HANOVER Gate, N.W. r.

December 30, 1928 .

To THE EDITOR OF THE Journal of Philosophical Studies.

SiR,

\section{MR. JOAD'S REPLY}

In reply to Mr. Henson's letter: (I) He is right in thinking that I do not regard the three types of Monistic theory referred to in my article as exhaustive. I am aware that there are other thinkers besides those mentioned who have regarded the universe as a unity. As a matter of fact, I expressly say on the first page of the article, "I propose to consider three different forms of the view that the universe is really a unity." It is, I think, a plain implication of this statement that there are other forms of the view which I do not propose to consider, and I do not understand, therefore, why Mr. Henson should wonder whether I think that I have disposed of all possible views of the unity of the universe, since it is clear that I do not think anything of the kind.

(2) The special difficulty which confronts those who venture to controvert with Hegelians is well known. This difficulty arises from the fact that Hegel said so many things, and so many of them are so exceedingly obscure, that it is always open to a Hegelian to baffle criticism by simply affirming that Hegel did not say what the critic says he said, or that, if he did, he did not mean by it what the critic thinks he meant.

The fact is that not only are there a number of rather different doctrines in Hegel's philosophy, but of most of them there are a number of interpretations. The existence of these different doctrines and interpretations is very convenient for the Hegelian apologist, enabling him to select whichever of them is most useful for controversial purposes at the moment, affirming that this is what Hegel really said, or that that is the true interpretation of what Hegel said. When the enemy has concentrated his fire on the position thus affirmed, it is a simple matter to move on to another one for which an equal show of authority can be produced.

This, I submit, is what Mr. Henson has done in the present case. According to his interpretation of McTaggart's interpretation of Hegel, the unity of the real is a number of persons. These persons are real "in exactly the same sense in which the Absolute is real." Moreover, they are composed of many different substances and distinguished by attributes which are real and really different. Reality is thus the Absolute plus many real persons separated by real differences both from it and from one another.

Now, if Hegel really meant this, I have no more to say. The position seems to me to involve a thoroughgoing pluralism, and as my criticisms are directed against Monism, they fall to the ground.

(3) But did Hegel mean anything of the kind? It will, I am convinced, come 


\section{O R R ES PON D E N C E}

as a shock to most Hegelians to hear that he did. In this connection I cannot help thinking that Mr. Henson is unwise to rely on McTaggart. That McTaggart's exposition of Hegel was, to say the least of it, unconventional is notorious. If Mr. Henson will turn to p. 123 of the number of the Journal in which my article appears, he will find in a review of Dr. Broad's recent essay on McTaggart the following sentence: "Broad admits that if McTaggart's account of Hegelianism be compared with Hegel's writings as a whole, one is impressed with their profound unlikeness, even though one hastens to add that the Swabian 'never meant anything so sensible, or plausible as this ' " I am not acquainted with McTaggart's exposition of Hegel, but, if Mr. Henson does not misrepresent it, I thoroughly agree with Dr. Broad.

Turning to a more authoritative exponent, Professor Caird, I find sentence after sentence which tallies with my account, while it belies Mr. Henson's. The universe, we are told, is, according to Hegel, an organic unity in difference. For a key to the understanding of this conception we are referred to self-consciousness. For selfconsciousness is a unity which "manifests itself in the difference of self and not-self, that through this difference, and by overcoming it, it may attain the highest unity with itself."

The unity admittedly is not a blank one; it is a unity of different aspects or elements. But I can find nothing about a plurality of real and really different persons existing apparently side by side with the Absolute. What I do find is a constant insistence upon the logical priority of the unity to the differences, expressions such as "reconciled in," "overcome in," "transcended by," being continually used to describe what happens to the differences in relation to the unity. The objective world ( 1 am here quoting Professor Caird), only reaches the "fullest realization of itself in a complete unity," and self-consciousness, upon the model of which the objective world is conceived, is spoken of as "the complete integration" of the differences that it transcends.

Now it cannot, I think, be seriously doubted that these expressions do truly represent Hegel's conception of the one and of its relation to the apparent plurality of the many. And it is precisely this conception that I have endeavoured to criticize on the ground that, if the differences are real, the unity is not really a unity; while, if the differences are apparent only, then the unity is a featureless blank which cannot be made responsible for the appearance of the differences.

Yours faithfully,

C. E. M. JOAD.

LONDON,

January 9, 1929.

To THE EDITOR OF THE Journal of Philosophical Studies.

DeAR Sir,

A review of my monograph entitled Phenomenology as a Method and as a Philosophical Discipline has appeared in the current issue of your Journal. Protesting emphatically against the judgment of the reviewer, I request the publication of my reply.

It is obvious that the reviewer has made no effort to understand the monograph. For if he had, there would have been no question concerning its purpose or the public for which it was intended, nor references to a "maze" of materials, nor aspersions concerning the philosophical grasp of the writer. Either the reviewer has not the necessary background to estimate such a work, or he is guilty of a superficial judgment of a carefully prepared essay which has already been well received by men of rank.

It is clear to the reader that the essay is devoted primarily to the exposition of Husserl's philosophy (for example, the entire chapter on the phenomenological method), and that the writer takes the opportunity of viewing certain basic philosophical problems in its light. Some material is introduced in the fifth chapter, on the "Perceptual Object," as well as in the opening chapter, in order to connect with Anglo-American philosophy. The larger parts of chapters two, three, and four (respectively "First Philosophy," "The Phenomenological Method," and "Transcendental 